\title{
The impact of copyright law on the digitization of library collections in academic libraries in Malaysia
}

\author{
Tay Pek San, ${ }^{1}$ Lim Heng Gee, ${ }^{2}$ Ida Madieha Abdul Ghani Azmi ${ }^{3}$ \\ and Sik Cheng Peng ${ }^{1}$ \\ ${ }^{1}$ Faculty of Law, University of Malaya, Kuala Lumpur, MALAYSIA \\ ${ }^{2}$ Faculty of Law, Universiti Teknologi MARA, Shah Alam, Selangor, MALAYSIA \\ ${ }^{3}$ Ahmad Ibrahim Kulliyyah of Laws, \\ International Islamic University of Malaysia, Kuala Lumpur, MALAYSIA \\ e-mail: tayps@um.edu.my (corresponding author); \\ henggeelim227@salam.uitm.edu.my; idamadieha@iium.edu.my; sikcp@um.edu.my.
}

\begin{abstract}
The advancements made to digital technology have enabled academic libraries today to digitize their collections as a continuing process of improving their services to the academic community. Various factors determine whether a library should embark on a digitization project and the extent of the digitization. These include the policy of the institution, its financial resources, its manpower, its technical capability and the legality of digitization under the copyright law of each country. The objective of this study is to examine how Malaysian copyright law impacts on the digitization of collections in academic libraries in this country. The focus is on materials which are in the form of literary works as these represent the bulk of most academic libraries' collections. The study discusses the principles of copyright law that have a direct bearing on digitization, the potential liability of libraries for copyright infringement, the circumstances under which digitization is exempted from copyright infringement and the options available to academic libraries to embark on digitization projects without infringing copyright law. The methodology used is the doctrinal research methodology in the discipline of law. The findings of this study serve to expand the current body of knowledge on how digitization of library collections in academic libraries may be carried out within the confines of copyright law. The recommendations are two-fold. First, academic libraries may digitize materials if the purpose is to cater to the needs of those who are visually or hearing impaired. Secondly, in other cases, digitization may only be carried out after obtaining a licence or an assignment of copyright from the copyright owner. It is hoped that the study would provide librarians with a better understanding of the copyright issues that arise from digitization and the principles of copyright law that govern digitization so that libraries can act within the confines of copyright law.
\end{abstract}

Keywords: Academic libraries; Digitization; Copyright infringement; Exceptions to infringement; Copyright licence; Assignment of copyright.

\section{INTRODUCTION}

Advancements made in information and communications technology in recent times have opened up opportunities for academic libraries to adopt new digital technologies to modernise and improve their services. An obvious example is the old card cataloguing system which is now replaced by the computerized library system. In the former, searching 
through a library's card catalogue for specific books or materials is a tiresome and timeconsuming task. In contrast, the computerized library system facilitates this task by making the search faster, more comprehensive and more accurate. The search may be conducted relatively easily with a few clicks of the keyboard. Also, where the materials are in analogue format, the simultaneous use of the materials by multiple users from different locations is not possible whereas this is feasible if the materials are in digital format.

Digitization of library materials is one of the most current methods of improving access to library resources (Fabunmi, Paris and Fabunmi 2006; Zhang and Gourley 2008). It has changed the expectations of library users who increasingly demand that traditional library materials in the form of books, monographs, research papers, manuscripts, theses, governmental documents and the like be made available in online, searchable formats (Schonfeld 2011). Today, it is necessary for academic libraries to embrace this development to enhance their services in support of teaching and research. By digitizing library collections, information will be accessible to multiple library users at the same time instead of being limited to the specific few who have access to the hard copies of the library materials. This also means that academic libraries can reduce the purchase of multiple physical copies of materials and, accordingly, lessen the financial constraints which many of them are currently facing in the light of dwindling budget for acquisition of library stocks (Pandey and Misra 2014). The users of the digital collection need not be physically present in the libraries' premises but may be located at different places. Apart from the advantage of easy access which digital libraries offer to users, digitization also plays an important role in the preservation of library materials (Conway 2010; Hudson and Kenyon 2007). The availability of digital versions will automatically reduce the demand for the tangible items and, therefore, lower the risks of damage, loss and deterioration. The process of digitizing and maintaining digital collections raises many issues including policy considerations, planning, budget, technical know-how, psychological preparation and retraining of library staff, development of metadata standards and the selection criteria for determining which items are to be digitized. One of the major issues concerns copyright law. This is because copyright law confers on copyright owners a bundle of exclusive rights to control the doing of certain acts in relation to the copyright works. More specifically, the digitization of materials from analogue format to digital format encroaches on the exclusive right of reproduction of copyright owners. When the materials in digital format are made available to library users, the copyright owner's exclusive right of communication of the work to the public is called into play. Therefore, in most cases, permission from the copyright owner is required before embarking on digitization activities.

This study examines how Malaysian copyright law impacts on the digitization of library collections in academic libraries. The outcome of the research contributes to an understanding of the copyright issues that arise when embarking on digitization projects in Malaysian academic libraries. The research provides insight into the options available to libraries to carry out digitization activities within the confines of copyright law. From the perspective of authors who own copyright in their works and publishers who own copyright in the published editions of works, this research advances our understanding of how the exclusive rights of these entities are applied specifically in the context of the digitization of library collections. 


\section{LITERATURE REVIEW}

\section{The global practice of digitization of library collections}

Studies focusing on the digitization of library materials often note the importance of the digitization of analogue collections as a growing tool to improve the services of libraries (Chauhan 2014; Conway 2010; Schonfeld 2011; Zhang and Gourley 2008). The use of information and communications technology in the field of library and information science has gained momentum all over the world as librarians across the globe have begun to embrace this technology in response to the rapid shift from analogue to digital information. This trend of shifting from print format to digital format is also a direct result of the expectations of library users who increasingly desire to have collections in electronic formats as they become more comfortable in the digital world.

In their study on the challenges and implications posed by the digitization of library resources for policy and planning, Fabunmi, Paris and Fabunmi (2006) found that prior to 1997, digitization projects in the USA were mainly associated with large academic libraries but an increasing number of public libraries today are now embarking on digitization projects as well. Similarly, Hudson and Kenyon (2007), researching on the impact of copyright on digitization practices in Australia, noted that the digitization of analogue collections is a growing tool to facilitate the missions of libraries in Australia. In the UK, a study by Joint (2008) revealed that digitization programmes offered an important way forward for libraries to develop their services. Joint found that where a generous supply of effective digital surrogates for print materials existed, library users would in most cases prefer the digital format to the print format. He also asserted that copyright law had a major impact on the digitization process in the UK and that the restrictive nature of UK copyright law was a significant factor inhibiting the migration from print to digital media. In India, Varatharajan and Chadrashekara (2007), noting the significant contribution of academic libraries to the transmission of knowledge, observed that digital libraries were an efficient way of making education and research data and information available to faculty, research and students. Similarly, in Indonesia, Sulistyo-Basuki (2004) provided an overview of digitization activities in academic libraries in Indonesia, starting from the initiatives of the Ganesha Digital Library Network in 1998 which developed into the Indonesian Digital Libraries Network.

In Malaysia, in a study conducted on the issue of risk in digitization projects by cultural institutions in Malaysia, Zuraidah and Aliza (2010) noted that all public cultural institutions, namely, the National Archives, Department of Museum, National Library and National Art Gallery had embarked on digitization initiatives. According to them, these cultural institutions had transformed into 'hybrid institutions' that not only took care of analogue materials but also digital cultural information and resources. One of the major risks in digitization projects in libraries which Zuraidah and Aliza (2010) identified was the ease of changing or erasing digital texts without leaving any traces of erasures. Also, the quality of the digital images is dependent very much on the expertise of the staff in utilizing the available technology. In addition, due to the rapid changes in technology, libraries must closely examine the best way of preserving the digital images so that they will be preserved even if the technology changes. The diversity of file formats and cost of migration are critical issues in digital preservation. The retrieval of digital objects is reliant on computers and Internet connections as well as hardware and software compatibility. Another risk of digitization which Zuraidah and Aliza (2010) identified is the management of disaster recovery during any emergency situations such as fires and floods. 


\section{The intersection between copyright law and digitization}

The impact of copyright law on the practice of digitization of library materials is widely acknowledged. This is because the process of digitization, which essentially converts a copy of the copyright work from analogue to digital format, encroaches on the exclusive right of copyright owners. While many of the issues and challenges posed by copyright law on the practice of digitization are common to libraries in most countries, the specific responses to the issues and challenges may differ from one country to another depending on each country's copyright law.

Two interesting studies focusing on the copyright issues in digitization were conducted by Hudson and Kenyon (2007) in Australia and the Office of the Register of Copyrights (2011) in the USA. Both studies investigated the extent to which copyright law impacted on the practice of digitization and the options available to libraries to carry out digitization activities without infringing copyright. Hudson and Kenyon (2007) found that copyright law affected what materials were digitized and how they were made accessible. They pointed out that amendments made to the Australian Copyright Act 1968, particularly in the years 2000 and 2006, had permitted a broader scope of acts to be carried out in order to enhance online access to collection materials. At times, this was done through allowing certain activities to be carried out under detailed, purpose-specific exceptions in the copyright statute. The study examined whether the goal of enhancing online access had been achieved through the amendments. It was found that there were certain anomalies and restrictions in the copyright statute which continued to hinder the development of digitization. For instance, the study found that in the vast majority of public uses, a licence or assignment from the copyright owner was required and this placed a high administrative burden on libraries. The study also found that the Australian copyright statute did not adequately address how institutions could obtain copyright clearance in cases of orphan works where it was difficult or impossible to identify or locate the copyright owner. The researchers suggested the need for continued debates on copyright exceptions and the possibility of new collective licensing models as ways of obtaining copyright clearance.

The Office of the Register of Copyrights (2011) in the US addressed the relationship between the digital marketplace and the existing copyright framework. It examined how digitization implicated copyright owners' exclusive rights and noted that libraries must consider the potential for copyright infringement when they digitize copyright works or make their scans available for public access without permission. The study observed that there were specific statutory exceptions in the US copyright law, such as fair use and reproductions by libraries, which might offer a defence to digitization. However, these only applied in some limited instances and were unlikely to cover all facets of the digitization projects. The study also examined the ways in which copyright owners could provide efficient and cost-effective licensing options as a means to obtain copyright clearance before embarking on digitization.

More recently, in the celebrated case of The Authors Guild, Inc v Google Inc (2013), the US District Court held that mass digitization of books by Google was permitted under the US fair dealing defence. In that case, The Authors Guild, which represented a number of US and non-US copyright owners, sued Google claiming that its Google Books Library Project, which was a mass digitization activity, infringed their copyright. Through this project, books were digitized, a searchable database was created and users could view snippets of the works which they searched. In 2013, the US District Court held that Google's digitization activities fell within the scope of the US fair use doctrine. According to the court, this was 
because the digitization of the books was highly transformative and beneficial to society. The digitization activities were transformative because they were carried out for a new and different purpose from the original. This decision was upheld in October 2015 by the US Court of Appeals for the Second Circuit in The Authors Guild v Google, Inc. An appeal by The Authors Guild was turned down by the US Supreme Court on 18 April 2016.

In Malaysia, there are scholarly works on copyright law which examine the exclusive rights of copyright owners under the Copyright Act 1987 ('CA 1987'), which is the statute governing copyright in Malaysia (Khaw 2008; Ida Madieha 2012; Tay 2013). While these works deal with the principles of copyright law in Malaysia and their interpretation as well as application by the local courts in decided cases, they do not specifically analyse the application of the principles in the context of digitization of materials by libraries in this country. This study attempts to fill the gap by analyzing how general copyright principles in Malaysia are to be applied to digitization activities by libraries so that legal rules may be formulated specifically to meet the context of digitization by libraries.

\section{OBJECTIVES AND METHOD}

The objective of this study is to understand how copyright law affects the digitization of library materials in academic libraries in Malaysia. The focus is on copyright materials which are in text form such as books, monographs, periodicals, newspapers, manuscripts, dissertations, documents, journals, reviews and any other forms of scholarly writings. These materials represent the substantial portion of academic libraries' core collection.

The study attempts to answer the following research questions:

a) What are the principles of copyright law that have a direct bearing on the digitization of library materials in academic libraries?

b) What are the legal consequences under copyright law that libraries expose themselves to when undertaking the digitization of library materials?

c) What, if any, are the types of digitization activities that are permitted by copyright law?

d) What are the options available to academic libraries so as not to infringe the rights of copyright owners?

This research adopts the doctrinal research methodology in the discipline of law. Manderson and Mohr (2002) state that doctrinal research is the most accepted legal research method and describe it as research into the law and legal concepts. It is concerned with the formulation of legal doctrines through the analysis of legal rules (Chynoweth 2008). In Malaysia, the law and legal concepts are to be found in court cases and statutory instruments such as statutes, regulations, rules and by-laws. However, these cannot, in themselves, provide a complete statement of the law in all situations (Chynoweth 2008). Instead, the relevant doctrines need to be applied to the specific facts of the situation under consideration in order to ascertain the rights and liabilities of the entities involved or the legality of particular activities. Doctrinal research methodology provides a systematic exposition of the legal principles governing a particular area of law, analyses the relationship between the principles, explains areas of difficulty and examines its application within a specific context (Pearce, Campbell and Harding 1987). In essence, it develops the legal doctrines so that the nature and parameters of the law in a particular context can be expressly formulated. For instance, the law of copyright in Malaysia is to be found in the CA 1987 as amended from time to time by Parliament, the various Regulations 
and Orders made under the Act and decided court cases which are binding precedents. However, these legal rules do not, in themselves, expressly deal with the legality of the activity of digitization of library materials. Rather, the relevant legal rules need to be examined, analysed and developed so that a considered opinion may be made on the legality of the activity.

Doctrinal research involves a two-part process (Duncan and Hutchinson 2012). First, the researcher must locate the relevant law and legal principles. This involves collecting all relevant materials from normative sources and authoritative sources (Van Hoecke 2011). In Malaysia, normative sources include statutes, subsidiary legislation, customary law and case laws which are binding precedents. Statutes can be in the form of an Act of Parliament, Enactment or Ordinance. Subsidiary legislation, as defined in section 3 of the Interpretation Act 1948 \& 1967, means 'any proclamation, rule, regulation, order, notification, by-law or other instrument made under any Act, Enactment, Ordinance or other lawful authority'. Case laws from other jurisdictions are persuasive authorities and do not amount to binding precedents. Authoritative sources include scholarly legal writing and foreign case laws which are of persuasive value. Case laws which are binding precedents are more relevant than those which are merely persuasive. Secondly, after locating and reading the relevant documents, the researcher must interpret and analyse them to ascertain the exact meaning and scope of the law. Once this is determined, the law is applied to the specific context in question. This synthesizing process may involve, where appropriate, deductive logic, inductive reasoning or inductive reasoning.

This research draws heavily on deductive logic for the second step. The basic syllogism for deductive logic comprises major premise, minor premise and conclusion. In this research, the major premise is that the Malaysian copyright law grants copyright owners the exclusive right to control in Malaysia the reproduction of their works in any material form, subject to a number of specified exceptions. The minor premise is that digitization of library materials by libraries amounts to a reproduction of copyright works. A conclusion on the legality of digitization activities undertaken by libraries is then drawn based on these two premises.

\section{BASIC PRINCIPLES OF MALAYSIAN COPYRIGHT LAW}

The basic principle behind copyright protection is the concept that the proprietary right of an author to his created work should be protected. The nature of that proprietary right is the exclusive right to exploit the work and, accordingly, to prevent others from interfering with that right. In Malaysia, copyright law places great emphasis on protecting the economic aspect of the exclusive right in the sense that the law's focus is on the protection of the copyright owner's commercial activities that are carried out with a view for profit. In contrast, many European countries which adopt the civil law system place importance on protecting the moral rights of authors in addition to their economic rights. Essentially, moral rights prevent violations of the author's personality. Examples of moral rights include the right of the author to be publicly identified as the creator of the work if it is used in public and the right to prevent distortion of his work.

Copyright law in Malaysia is governed by the Copyright Act 1987 ('CA 1987'), the various Regulations and Orders made under it and locally decided case laws. Protection is given to the following types of works: literary works, musical works, artistic works, films, sound recordings, broadcasts, typographical arrangements of published editions of works and 
derivative works (CA 1987, sections 7, 8 and 9). Derivative works are works that are derived from other works which are eligible for copyright, such as translations, adaptations and arrangements. Collections of works eligible for copyright, such as a collection of essays, fall within the category of derivative works. Databases are also derivative works if they constitute intellectual creation by virtue of the selection and arrangement of the contents (CA 1987, section 8(1)(b)).

Copyright protection is only conferred on works which are original. Originality in copyright law means the work must originate from the author and sufficient effort has been expended to create the work (CA 1987, section 3(a)). Copyright protects the form of expression of a work and not its underlying idea (CA 1987, section 7(2A)). For instance, mathematics textbooks often contain the same mathematical principles for each particular topic. Copyright protection is conferred on the form of expression which the author uses to express the mathematical principle and not on the principle itself.

The work must also be embodied in some material form in the sense that it must be written down, recorded or stored in any form of storage from which the work can be reproduced (CA 1987, section 3(b)). However, copyright protection is conferred on the underlying work and not the physical object that embodies the work. A distinction is therefore made between the property in the copyright and property in the physical object that embodies the work. For instance, in the case of a novel, copyright is conferred on the copyright owner of the work who is usually either the author or the publisher. An institution that purchases a copy of the book is the owner of that physical copy but not the copyright in the underlying work.

There is no requirement for a work to be registered in order to be conferred copyright protection. Indeed, in Malaysia, there does not exist any legal procedure for the registration of a work in order to acquire copyright protection. In the year 2012, an amendment was made to the CA 1987 to provide for the creation of a Register of Copyright (CA 1987, sections 26A and 26B). The new provision allows the voluntary notification by a copyright owner to the Controller of Copyright that he is the copyright owner of the work. The Register serves as prima facie evidence of copyright ownership but does not confer on the work any additional right that it did not enjoy.

In addition to the requirement that a work must be original and reduced to a material form, it is also necessary that one of the three qualifications for copyright protection spelt out in section 10 of the CA 1987 is met. The first qualification is that the author is a Malaysian or a permanent resident of Malaysia. This qualification is also met if the author is a citizen or a permanent resident of a Member State of the Berne Convention for the Protection of Literary and Artistic Works 1886 ('Berne Convention'). The Berne Convention is the first international convention on copyright. The second qualification is that the work is first published in Malaysia or a Member State of the Berne Convention. The third qualification is that the work is made in Malaysia or a Member State of the Berne Convention.

The copyright owner of a work enjoys copyright protection for a limited duration which depends on the nature of the work. In academic libraries, the core collection of works typically comprises textbooks, reference books, journals, reports, governmental documents, theses, dissertations, research papers and similar items. In most cases, these works are protected by copyright as literary works and the duration of their copyright is life of the author plus fifty years after his death (CA 1987, section 17(1)). Apart from the 
literary copyright, where a work is published, there exists an additional copyright in the work, namely, copyright in the published edition of the work. Essentially, copyright in the published edition belongs to the publisher of the edition. It grants to the publisher the exclusive right to control the reproduction of the typographical arrangement of the edition. The duration of copyright in a published edition is 50 years from the beginning of the next year following the publication of the edition. As a result of these two copyrights that can simultaneously subsist in a work, it is possible for a situation to occur where the literary copyright in a work has expired but the copyright in the published new edition continues to subsist. The current duration of copyright is set out in Table 1.

Table 1: Duration of Copyright

\begin{tabular}{|c|c|c|}
\hline $\begin{array}{l}\text { Section in the } \\
\quad \text { CA } 1987\end{array}$ & Type of work & Duration of copyright \\
\hline 17 & $\begin{array}{l}\text { Literary, musical and } \\
\text { artistic works }\end{array}$ & $\begin{array}{l}\text { (i) If the work is published during the lifetime of the } \\
\text { author, the duration is life of the author plus fifty } \\
\text { years } \\
\text { (ii) If the work is unpublished during the lifetime of } \\
\text { the author, copyright subsists until fifty years from } \\
\text { the beginning of the next year following its } \\
\text { publication } \\
\text { (ii) If the work is published anonymously or under a } \\
\text { pseudonym, the duration is fifty years from the } \\
\text { beginning of the next year following its publication }\end{array}$ \\
\hline 18 & Published editions & $\begin{array}{l}\text { The duration is fifty years from the beginning of the } \\
\text { next year following the publication of the edition }\end{array}$ \\
\hline 19 & Sound recordings & $\begin{array}{l}\text { (i) If the sound recording is published, the duration is } \\
\text { fifty years from the beginning of the next year } \\
\text { following its publication } \\
\text { (ii) if the sound recording is not published, the } \\
\text { duration is fifty years from the beginning of the next } \\
\text { year following the making of the sound recording }\end{array}$ \\
\hline 20 & Broadcasts & $\begin{array}{l}\text { The duration is fifty years from the beginning of the } \\
\text { next year following the making of the broadcast }\end{array}$ \\
\hline 22 & Films & $\begin{array}{l}\text { The duration is fifty years from the beginning of the } \\
\text { next year following the publishing of the film }\end{array}$ \\
\hline 23 & $\begin{array}{l}\text { Works of the } \\
\text { Government, } \\
\text { government } \\
\text { organisations and } \\
\text { international bodies }\end{array}$ & $\begin{array}{l}\text { The duration is fifty years from the beginning of the } \\
\text { next year following the publishing of the work }\end{array}$ \\
\hline
\end{tabular}

If a literary work such as a thesis, monograph, research paper or manuscript has not been published, the copyright in the work will continue to subsist until after 50 years from its publication. A literary work is deemed to have been published if a copy or copies of the work have been legally made available to satisfy the reasonable requirements of the public (CA 1987, section 4(1)). The 50 years is computed from the beginning of the next year 
following its publication (CA 1987, section 17(2)). This means that an unpublished work can potentially enjoy perpetual copyright protection. In practical terms, this could create difficulties for researchers who wish to make copies of parts of the work because of the difficulties in tracing and determining the owner of the copyright (Khaw 2008). Where the copyright in a work has expired, the work falls into the public domain. A work which falls into the public domain does not enjoy any copyright protection. For works which are in the public domain, digitization may be carried out without any copyright constraint because the copyright owner's exclusive rights have come to an end.

Copyright law confers on the copyright owner a bundle of exclusive rights to control the carrying out of certain acts in relation to the work. Of these rights, two important ones in relation to the digitization of library materials are the right to control the reproduction of a work in any material form (CA 1987, section 13(1)(a)) and the right to communicate the work to the public (CA 1987, section 13(1)(aa)). The term 'reproduction' has a legal meaning and is defined in section 3 of the CA 1987 as the making of one or more copies of the work in any form or version. This includes converting a copy of a work which is in analogue form to digital form. The same section defines 'communication to the public' as the transmission of a work through wire or wireless means to the public (CA 1987, section $3)$. The right to communicate the work to the public is called into play once the digitized works are disseminated.

Apart from the exclusive rights mentioned above, which are essentially commercial in nature, the CA 1987 confers moral rights on the author of a work (CA 1987, section 25). Moral rights are personal to the author of the work. There are two types of moral rights provided in Malaysia. The first is the right to be identified as the author of a work. The second is the right to prevent any unauthorized distortion, mutilation or other modification of the work where it significantly alters the work and might reasonably be regarded as adversely affecting the author's honour or reputation.

Copyright in a work is infringed by a person who, not being the copyright owner, performs an act that falls within the exclusive rights of the copyright owner (CA 1987, section 36(1)). The act may be in relation to the whole of the work or a substantial part of it. Whether or not a part of a work is substantial is assessed from a qualitative and quantitative perspective. For instance, it is an infringement of copyright to digitize the whole of a book which is in analogue form or a substantial part of it without the prior permission of the copyright owner.

The CA 1987 provides some specific exceptions to copyright infringement. Acts which fall within any of the exceptions do not infringe copyright and therefore may be carried out without the permission of the copyright owner. In relation to digitization, three exceptions are important to academic libraries. These are the fair dealing exception (CA 1987, section 13(2)(a)), the use of a work by educational institutions exception (CA 1987, section 13(2)(i)) and the exception for people with visual or hearing impairment (CA 1987, section 13(2)(gggg)). As these exceptions apply only if the specified requirements stated in the sections are met, this aspect will be further elaborated below.

Where a work is protected by copyright and the intended activity in relation to the work does not fall within any of the copyright exceptions, prior permission must be obtained from the copyright owner. The permission takes the form of a licence that is in writing (CA 1987, section 27(3)). There are different types of licences that a copyright owner may grant. Being an agreement, the terms of the licence can assume varied forms such as a 
perpetual licence for non-commercial activities, licence for all types of activities, licence that is limited by duration and licence that is limited to geographic area. In some cases, an institution may wish to purchase the copyright in a work from the copyright owner. This is done by way of an assignment, which has the effect of transferring the property right in the copyright from the copyright owner to the institution (CA 1987, section 27(1)). Once assigned, the institution is conferred with the exclusive rights of a copyright owner and may digitize the work without having to seek any further permission.

\section{DISCUSSION AND APPLICATION OF COPYRIGHT PRINCIPLES TO DIGITIZATION}

When a library material is digitized, it is scanned or photographed page by page and an identical copy of the work is made in digital form. In applying the copyright principles discussed in the previous section to the specific context of digitization of library materials, the ensuing discussion will address the four research questions set out in the beginning of the paper.

\section{Research question 1: What are the principles of copyright law that have a direct bearing on the digitization of library materials in academic libraries?}

The digitization of library materials amounts to a reproduction of those materials. The copyright owner has the exclusive right to control the reproduction of the work in any material form. The reproduction right is not confined to merely a right to control the making of duplicate or facsimile copies but extends to the making of copies in a medium different from that of the original. The fact that the reproduction is not in the same analogue format but is in digital form with $0 \mathrm{~s}$ and $1 \mathrm{~s}$ of digital data is irrelevant because the definition of 'reproduction' in the CA 1987 is sufficiently wide to include copies made in any form or version. In addition, the 'material form' which embodies a copy of the work may be in any visible or non-visible form of storage. This includes storage of the digitized work in a server or the cloud or in computer devices such as the USB flash drive and the hard disk of a computer.

The reproduction right covers the right to control not only reproduction of the whole work but also a substantial part of it. Hence, digitizing part of a work is not permitted under copyright law if the digitized part amounts to a substantial part of the copyright work. What amounts to a substantial part is to be determined qualitatively and quantitatively. Factors such as whether the author had expended sufficient skill and labour in writing the part that was digitized so as to render that part an original literary work and whether the digitized part would interfere with the sales of the work are relevant considerations to take into account in determining substantiality. Although in theory, digitizing insubstantial parts of a work is not infringement of copyright, this is rarely feasible. When libraries undertake digitization projects, the practical reality is that the whole work or, at least, a substantial part of it is digitized. This activity is clearly within the control of the copyright owner of the work.

Aside from the reproduction right, where the digitization is carried out for the purpose of creating a digital repository so that the academic institution's community, such as its students, academic staff or paid subscribers, can have access to the digital works, the exclusive right of the copyright owner to control communication of the work to the public is called into play. The nature of this right is the right to control the transmission of a work through wire or wireless means to the public. This includes allowing access to the digitized 
work through the institution's website or onsite terminals. The phrase 'the public' has a broad meaning in that it is not confined only to the general public but includes members of a section of the public. Hence, members of the institution's community qualify as 'the public' and, accordingly, making the digitized works available to its members through the institution's computer network falls within this exclusive right of the copyright owner.

\section{Research question 2: What are the legal consequences under copyright law that libraries expose themselves to when undertaking the digitization of library materials?}

As the digitization of materials falls within the ambit of the exclusive reproduction right of copyright owners, such activities can only be carried out by the copyright owners themselves unless the libraries obtain prior permission from them or the acts are specifically permitted by the CA 1987 . The acts which are specifically permitted by the CA 1987 are discussed below. In the absence of these, libraries run the risk of legal actions being brought against them for copyright infringement (CA 1987, section 36).

Where a library engages an independent contractor to carry out the digitization project, both parties are equally liable for copyright infringement even though the actual act of digitization is carried out by the independent contractor. This is because under the CA 1987, infringement is committed by the person who does the act or causes any other person to do the act (CA 1987, section 36(1)). The word 'causes' has been held to cover the situation where a person is in a position to exercise control over another person, for instance, as a principal or employer (Marsh v Conquest, Khaw 2008).

\section{Research question 3: What, if any, are the types of digitization activities that are permitted by copyright law?}

In some situations, albeit very limited ones, libraries may digitize the materials in their collection without obtaining the prior permission of the copyright owners. In this regard, three sets of exceptions are relevant. The first is the fair dealing exception (CA 1987, section $13(2)(a))$. The second is the use of a work by a prescribed educational institution (CA 1987, section 13(2)(i)). The third is the making of copies into a format suitable for the visually or hearing impaired people (CA 1987, section 13(2)(gggg)). This exception was newly introduced by the latest amendment to the CA 1987, which is the Copyright (Amendment) Act 2012.

The first exception is the fair dealing exception which allows digitization to be carried out for purposes such as research or private study provided that the digitization is fair in the circumstances. In assessing whether the digitization is fair, four factors need to be taken into account (CA 1987, section 13(2A)). The first factor is the purpose and character of the dealing, including whether such dealing is of a commercial nature or is for non-profit educational purposes. The primary aim of digitization of library materials is for preservation and easy access by students, teaching staff and researchers and not for commercial purposes (Pandey and Misra 2014). This would satisfy the first requirement of fairness. The second factor to take into account is to consider the nature of the copyright work that is digitized. Where the work is primarily factual rather than creative in nature, it is easier to satisfy the fairness requirement. However, most materials in academic libraries' collection, whether in the arts, sciences or humanities disciplines, are created with an appreciable degree of creative input. Digitizing those works without permission of the copyright owner is unlikely to be fair. The third factor is the amount and substantiality of the portion used in relation to the copyright work as a whole. Again, digitization by 
academic libraries inevitably involve digitizing the whole work and this would militate against it qualifying as fair. The final factor is the effect of the dealing upon the potential market for or value of the copyright work. Once a work is digitized and stored in digital repositories, the work may be viewed by multiple library users simultaneously. This obviates the need to purchase multiple physical copies of the work and would have a direct impact on the market for the copyright work. In light of this, it is highly unlikely that fair dealing would provide a safe justification for academic libraries to embark on digitization projects.

The second exception is the digitization of library materials by educational institutions where such digitization is in the public interest and is compatible with fair practice. In addition, no profit is to be derived from the digitization and no admission fee is to be charged if the work is shown to the public. The phrase 'public interest' is a broad concept which covers many activities including education (Khaw 2008). There is the further requirement that the digitization must also be compatible with 'fair practice'. As the phrase 'fair practice' is not defined in the CRA 1987 nor has it been judicially interpreted, it has been suggested that it bears the same meaning as 'fair dealing' (Khaw 2008). Further light on the scope of this exception may be shed by Article 9(2) of the Berne Convention which requires that any exemption from copyright should not conflict with a normal exploitation of the work and should not unreasonably prejudice the legitimate interests of the author. As a result of the requirements that need to be satisfied for this exception to apply, it would appear that the exception would permit digitization for the purpose of preserving the library material against loss or deterioration but not for replacement purpose where the material is lost or stolen. The exception is likely to apply also in respect of out-of-print books or materials. However, the exception does not apply where the digitization is merely for the purpose of facilitating easier on-line access or research by students, teaching staff and other library users.

The third exception is the digitization of library materials in order to cater to the needs of those who are visually or hearing impaired. Under this exception, digitization of library materials by non-profit making bodies or institutions may legally be performed if its purpose is to convert the analogue work into a format to cater for the special needs of people who are visually or hearing impaired. Clause 11 of the Explanatory Statement to the Copyright (Amendment) Bill 2010 states that the exception was intended to allow modifications to be made to works so that they can be converted into a format suitable for people with vision or hearing impairment. This exception applies only in the context of meeting the needs of those who are visually or hearing impaired. Outside of this exception, digitization activities which are carried out for the purpose of creating a union database of online journal collections that compile all the articles from a library's subscribed journals is not permitted as this amounts to a reproduction of the articles, which infringes the exclusive right of the copyright owner.

\section{Research question 4: What are the options available to academic libraries so as not to infringe the rights of copyright owners?}

Pursuant to the CA 1987, two options are available to academic libraries to clear copyright. These are by way of a licence or an assignment of copyright from the copyright owner to the academic library or institution (CA 1987, section 27). In both cases, these are required to be in the form of writing (CA 1987, section 27(3)). Where the library materials are in the form of books, it is common that the book publisher is the copyright owner. A licence is different from an assignment. A licence is permission granted by the copyright owner to 
another entity to perform acts which fall within the copyright owner's exclusive rights in relation to the work. The copyright in the work remains with the copyright owner at all times. For instance, some Creative Commons licence grant permission to licensees to copy, distribute, display and make derivative works for non-commercial purposes. This defines the scope of the permission granted to the licensee but the copyright in the work remains with the copyright owner. In contrast, in assignments, the copyright is transferred to the other entity. There is a transfer of property right from the copyright owner to the new entity.

There may be cases where academic libraries would obtain an assignment from the copyright owner, such as where the copyright owner does not see any benefit accruing to himself in retaining the copyright or where the copyright owner does not wish to control future institutional use of the work. However, it is evident that this would be rare and in the majority of cases, licences would be involved instead. The use of a licence in preference to an assignment may be seen in most books stating in their front page that no part of the publication may be reproduced or stored in any retrieval system of any nature without the prior permission of the publisher or, in some cases, the author. Since a licence is in effect contractual in nature, the academic library will have to negotiate the terms of the licences separately for each work that is digitized. It is conceivable that in at least some cases, fees to the copyright owner would be involved especially where he seeks to make a living with the work. The terms of the licence may be in various forms such as a perpetual licence for non-commercial activities, a licence that is limited by duration, a licence that is granted exclusively only to the academic library or a non-exclusive licence. The terms of the licence may also deal with whether the digital file may be published on the institution's website, whether the digital file may be read in the library only or may be accessed from a remote location, whether there should be dedicated terminals in the library to access the digital files, whether library users can print out the copies or store them in a USB stick, the number of digital readers who can have access to the digital copies at any one time and the fee to be paid for each page viewed.

However, there are practical drawbacks for academic libraries when seeking licences as well. As digitization would involve numerous materials in the library's collection, the total cost of the licence fees may be staggering and become prohibitive for the institution. Aside from this, there is also the administrative expense of identifying and locating the copyright owner in the first place, negotiating the terms of the licences and managing the licences.

\section{CONCLUSION}

This study identifies two exclusive rights of copyright owners which are impinged upon when academic libraries undertake the digitization of library materials. These are the exclusive right of a copyright owner to control the reproduction of a work and the right to control communication of the work to the public. The copyright owner's right of reproduction is called into play because the act of digitizing essentially involves converting the copyright work from analogue format to digital format. The copyright owner's right to control communication of the work to the public is also relevant in the context of library digitization when the digitized work is made available to library users through computer terminals.

This research contributes to an understanding of how digitization of library collections in academic libraries may be carried out within the confines of copyright law. The 
recommendations are two-fold. First, academic libraries may digitize materials if the purpose is to cater to the needs of those who are visually or hearing impaired. Secondly, in other cases, digitization may only be carried out after obtaining a licence or an assignment of copyright from the copyright owner. Under the CA 1987, prior permission may be obtained through the grant of a written licence by the copyright owner. As licences are contractual in nature, the detailed terms of one licence are likely to differ in substance from that of another. Unlike countries which have reproduction rights organization to licence reproduction rights on behalf of copyright owners, Malaysia does not have such a collective management organization and, accordingly, private negotiations have to be carried out on a case by case basis between the institution and the copyright owner.

\section{ACKNOWLEGEMENTS}

This research did not receive any grant from any funding agency in the public, commercial or not-for-profit sector.

\section{REFERENCES}

Chauhan, H. 2014. Moving beyond library automation: Role of digitization in academic library. Available at http://ssrn.com/abstract $=2494747$.

Chynoweth, P. 2008. Legal research in the built environment: a methodological framework. Available at http://usir.salford.ac.uk/12467/1/legal_research.pdf.

Conway, P. 2010. Preservation in the age of Google: Digitization, digital preservation, and dilemmas. The Library Quarterly: Information, Community, Policy, Vol. 80, no. 1: 6179.

Copyright Act 1987 (Act 332).

Copyright (Amendment) Bill 2010.

Duncan, N.J. and Hutchinson, T. 2012. Defining and describing what we do: Doctrinal legal research. Deakin Law Review, Vol. 17, no. 1: 83-119.

Explanatory Statement to the Copyright (Amendment) Bill 2010.

Fabunmi, B.A, Paris, M. and Fabunmi, M. 2006. Digitization of library resources: Challenges and implications for policy and planning. International Journal of Africa America Studies, Vol. 5, no. 2: 23-36.

Hudson, E. and Kenyon, A.T. 2007. Digital access: The impact of copyright on digitization practices in australian museums, galleries, libraries and archives. UNSW Law Journal, Vol. 30, no. 1: 12-52.

Ida Madieha, A.G.A. 2012. Copyright law in Malaysia: Cases and commentary, $2^{\text {nd }}$ ed, Petaling Jaya, Malaysia: Sweet \& Maxwell.

Khaw, L.T. 2008. Copyright Law in Malaysia, $3^{\text {rd }}$ ed, Petaling Jaya: LexisNexis.

Manderson, D. and Mohr, R. 2002. From oxymoron to intersection: An epidemiology of legal research. Law Text Culture, Vol. 6: 165-183.

Matulionyte, R. 2016. 10 years for Google Books and Europeana: Copyright law lessons that the EU could learn from the USA, International Journal of Law and Information Technology: 1-28.

Joint, N. 2008. Is digitization the new circulation?: Borrowing trends, digitization and the nature of reading in US and UK libraries, Library Review, Vol. 57, No. 2: 87 - 95.

Marsh v Conquest (1864) 17 CB (NS) 418, 144ER 169. 
Office of the Register of Copyrights, United States Copyright Office. 2011. Legal issues in mass digitization: A preliminary analysis and discussion document. Available at http://copyright.gov/docs/massdigitization/USCOMassDigitization_October2011.pdf.

Pandey, P. and Misra, R. 2014. Digitization of library materials in academic libraries: Issues and challenges. Journal of Industrial and Intelligent Information, Vol. 2, no. 2, 136-141.

Pearce, D., Campbell, E., and Harding, D. 1987. Australian law schools: A discipline assessment for the Commonwealth Tertiary Education Commission. Canberra: Australian Government Publishing Service.

Schonfeld R.C. 2011. What to withdraw? Print collection management in the wake of digitization. The Serials Librarian, Vol. 60, 141-145.

Sulistyo-Basuki, L. 2004. Digitization of collections in Indonesian academic libraries. Program: Electronic Library \& Information Systems, Vol. 38, no. 3: 194-200.

Tay, P.S. 2013. Intellectual Property Law in Malaysia Petaling Jaya: Sweet \& Maxwell.

The Authors Guild, Inc v Google Inc 954 F Supp 2d 282 (14 November 2013).

Van Hoecke, M. 2011. Legal doctrine: Which method(s) for what kind of discipline?. In Van Hoecke, M (ed.). Methodologies of Legal Research: What Kind of Method for What Kind of Discipline? Oxford: Hart Publishing.

Varatharajan N. and Chandrashekara,M. 2007. Digital library initiatives at higher education and research institutions in India. Library Philosophy and Practice, Vol. 9, no. 2: 1-7.

Zhang, A.B. and Gourley, D. 2008. Creating digital collections: A practical guide. Oxford: Chandos Publishing.

Zuraidah, A.M. and Aliza, I. 2010. Malaysian cultural heritage at risk? A case study of digitization projects. Library Review, Vol. 59, no. 2: 107-116. 